\title{
An Interpretation of Muhammad
}

\author{
Li Liu \\ School of Humanities, Qujing Normal University \\ Qujing 655011, Yunnan, China \\ E-mail: xqerin@126.com
}

Received: April 14, 2011

Accepted: April 29, 2011

doi:10.5539/ach.v3n2p41

\begin{abstract}
There is a meaningful background of social reform for Mohammed to create the monotheism for the Arabian world. He reformed the religion of the Arabian tribes and established Islam, the supremacy of faith, of only one god. Meanwhile, on the basis of religion, he transformed the social structure of the original tribal clan and broke the shell of Arabian tribal system, as laid a foundation for the unified national country. Therefore, his creation of the religion and the missionary activities bore the significance of social revolution. He was not only a religious prophet but a reformer.
\end{abstract}

Keywords: Islam, Prophet, Reform

Mohammed, the creator of Islam, one of the most influential religions in the world, is known as the great man making historical miracles. In the year of 610, he claimed that he heard Allah's "revelations" for the first time and began creating and missionary activities. In his pilgrimage in the year of 632 to Mecca, he delivered his famous speech, that is, the last "revelation". In the name of Allah's "revelation", he said, "today, I have sacrificed myself for you for the sake of your religion. And I have completed the grace I shall give to you. I have chosen Islam as your religion". He declared the victory of Islam. In the short period of 23 years, Muhammad had not only set up a new monotheistic religion for the Arabs as the national religion, but also created a unified Arabian country out of the chaos in the Arabian Peninsula. What is more worthy of our concern is that Islam did not end after the death of Muhammad, but develops rapidly from a national religion into a world religion. However, such a great man as Muhammad has always been understood as a religious figure in the world. And the mysterious religious aura has gradually masked his unique temperament and personality as a particular social member under certain historical conditions. When we recall the great 23-year creation of the religion, it is not difficult to see that he is not only a prophet but a reformer daring to break the tradition and an aspiring politician as well.

\section{A prophet}

It is said that Muhammad's mother had heard the voice from the angels while she was in pregnancy, saying that a prophet would be born. When Muhammad was very young, two angels appeared and took the snow from the gold plate to erase the evils from his heart. A Christian hermit had also predicted that the 12-year-old Mohammed would have an incalculable bright future. All the legendary words with religious mysterious color about the identity of Muhammad aimed at proving that he had been recognized as a prophet by some monotheistic believers. Although these words were certainly apocryphal, Muhammad had some temperament of a prophet, as was beyond doubt.

As far as the sense of religion is concerned, prophets are the spokesmen of God in the secular world. They exhaust themselves in the earth to try to awaken the souls of people to return to God. At the same time, they pass the God's will to all the fresh for they are the intermediaries or interveners between God and man. In the cultural vision, the prophets stand in the forefront of the nation for they have their unique and strong national consciousness and keen sense of the times, the pioneers and frontiers of their nation. They lead the direction of the nation, attract the eyeballs of the people, knock the soul of the confused, mold the unshakable national spirit and defend the honor of the nation. They clearly know that "when a nation has completely lost the spirit represented by a religion, its culture will be made flat and superficial in the secular world." Besides, it can become decayed or disintegrated due to the loss of spirit, for the ultimate spirit is not only the source of vitality, but a source of unity."(He, 2005, P6). When Arabs of "times of savagery" (See note) was in the phase of military democracy of the disintegration of clan system, each tribe had its own god. However, the cults are nothing but 
parts of the original worship of natural objects, rather than the religious system which produces an important impact on the national spirit. Influenced by the concept of sole divine spirit of Judaism and Christianity, Muhammad was no doubt aware of it. So, with a strong national sense of responsibility and lofty inner vision, he began to create and disseminate the only god of himself. He hoped to utilize the power of faith to express new ideas of Arabian society and the new code of ethics. He anticipated that the Arabs converting to Islam had completely broken with traditional concepts, so that their daily religious life and secular life could initiate led by a new religious system.

Prophet Muhammad has been bringing the impacts to the Arab world to this day. Muslims have a strong belief in him. They believe that Muhammad is the Messenger of Allah, a true servant following God's will to engage in religious activities.

\section{A reformer}

There is a meaningful context of social reform for Mohammed to create the monotheism for the Arabian world. By transforming the religion of the Arabian clan, he established Islam, which believes in the only one god of the supremacy. One the basis of the original religion, he reformed the social structure of the tribal clan, thus breaking the shell of Arabian clan system and laying a social foundation for a unified nation. Therefore, his creation of the religion and preaching bore a meaning of social revolution. He did not have the identity of a religious prophet, but a reformer. According to Arab poems and tales, before the rise of Islam, the Arabian society in general was still a kinship-based clan society. The clans were the foundation of society. People in the same region shaped a clan and those clans that recognized the same ancestor formed a tribe, which was a basic social and military organization and worshiped the same common enshrined rituals and customs. However, the primary factor in maintaining the tribal unity was the kinship. In clan emotions, the collective honor and interests were supreme and the pure and noble lineage was the most important. Outside the tribe, there were no common interests and power and people could not be bound by tribal traditional norms. As far as the Arabian social customs and conventions at that time were concerned, "outsider" and "enemy" was synonymous. But in socio-economic aspects, natural conditions on the Arabian Peninsula determined the nomadic economy as their main way of life. Based on such a socio-economic background, for 100 years before the rise of Islam, the Arabs had been always in continuous tribal warfare, which is known as the advanced stage of barbarism or the heroic age. However, long-term tribal fights weakened the strength of the Arabian tribes and made Arabian community lose the sense of security. The cruel social reality of the Arabian world called for the formation and expansion of tribal alliance. And such social development would inevitably result in the change of status of the original members of society. And the equality in the clan system had gradually disintegrated. The leaders of the tribal alliance had gradually become the aristocracy enjoying social privileges. Class differentiation appeared in the Arabian society. At the same time, commercial and economic development in some area produced the classes of renter and commercial aristocracy, and different economic status also caused different class differentiation. Thus contradictions and conflicts between classes became fiercer and fiercer. In addition, under such a complex socio-economic background, the Arabian Peninsula also had to face the invasion of foreign enemies, which exacerbated the existing social conflicts and social crises. In such social realities, the only feasible solution was to find ways to implement the unification of the Arabian tribes to end the long time wars among them. A unified national force was employed to fight against the alien invasion and control to restore the prosperity of the Arabian Peninsula. Muhammad, who lived in this social context, had lofty ambitions and clearly saw the needs for social change. He launched the Islamic movement, which actually reflected the requirements of social transformation. To realize it, Mohammed needed a powerful force to help him achieve the inter-tribal unity. Judaism and Christianity, which had produced great influences on Arabs, opened a window for him and let him see the power and cohesion brought by such beliefs. When a nation reached a consensus in faith, it is certain for it to be unified in social and political fields. Using the power of religion, Muhammad put forward a series of Islamic systems and a variety of religious systems to expound new thoughts in society, politics, economy and so on. Social reforms quietly began. His religious teachings and social advocates quickly won him the support from the people. Especially, the lower classes of the people showed strong resonance and a large number of believers had take refuge to Islam. He established the Muslim army and in it he conducted a series of political, economic, religious constructions. On the basis of a unified Islamic faith, Uma, a new social organization, was built, as completely broke the old boundary of the clan. He made Uma eventually become a regime of political and religious combination. And Mohammed himself became the real religious, political, judicial and military leader as an emissary of God. At the same time, he also completed a series of reforms from the national consciousness, national feelings to the social, political, economic, and ethical fields in Arabian tribes, as created a great miracle in the world's religious and political history. Although, Mohammed and his religious revolution was in consistent with the historical 
process from the tribes to nation and country and he showed his great wisdom and unique temperament in it. First he started to end the original polytheism with monotheism to unify the religious belief of Arabian nation, cultivate the unified Arabian national emotion and national consciousness, and injected new cultural source and vitality into the Arabian nation. Meanwhile, he put new social, political, economic and ethical elements into the religious belief of Islam. Religious movement thus was turned into a social and political campaign of Arabs. All shows that Muhammad himself was not only a prophet with unique sensitivity and intelligence, but also a social reformer and politician with foresight and ambition.

Note: Muslims name the era before the rise of Islam as times of savagery to show the difference from the Islamic period.

\section{References}

He, Guanghu. (2005). Meaning Beyond Words, 01.

Jin, Yijiu. (2006). Islamic History. Jiangsu Renmin Press, 01.

Lv, Taiji. (2003). Religious Studies Program. Higher Education Press, 12. 